\title{
INDONESIAN JURISPRUDENCE: ISLAMIC LAW TRANSFORMATION IN LAW SYSTEM OF INDONESIA
}

\author{
Ahmad Edwar \\ STAI KH. Abdul Kabier Serang \\ Email: ahmadedwar9@gmail.com
}

\begin{abstract}
This study discusses about the idea of Islamic law renewal in Indonesia, as well as the figures, and it makes the term of Indonesian Jurisprudence and its formalization into the law system of Indonesia. The purpose of this study is to find the answer of these following points: Firstly, the interpretation or definition of Indonesian Jurisprudence concept; secondly, the figures who proposed Indonesian Jurisprudence and the result of their thoughts; and the third, the formalization of Jurisprudence concept with Indonesian nuance in the law system Indonesia. This study was a library research with a content analysis method. The results of this study are: (1) Indonesian Jurisprudence could be interpreted as a Jurisprudence concept that is more Indonesian local-based; (2) Hasbi As-Shiddiqi and Hazairin are two figures who proposed Indonesian Jurisprudence model, apart from other intellectuals. Hasbi is one of modernists who offered his ideas comprehensively, started from his "Indonesian Jurisprudence" concept until the law renewal including its principle and method. Meanwhile Hazairin offered the development of a new heritage system which interpreted and elaborated based on Al-Qur'an scriptural perception and Sunnah which is not a patrilineal system but bilateral (family model); and (3) formalization of Indonesian Jurisprudence concept produces some ordinance regulation products which are important formally and materially, such as Ordinance of Islamic Marriage Law, and also other rules under the Ordinance, such as Government Law, President Instruction, and Supreme Court Law, as well as Islamic Law Compilation and Sharia Economic Law Compilation.
\end{abstract}

Keywords : Islamic Law Renewal, Indonesian Jurisprudence, Formalization, National Law 


\begin{abstract}
ABSTRAK
Penelitian ini membahas tentang ide pembaharuan hukum Islam di Indonesia beserta tokoh-tokohnya, hingga munculnya istilah Fiqh yang bernuansa keindonesiaan, hingga formalisasinya ke dalam sisten tata hukum di Indonesia tujuan dari penelitian ini adalah untuk mencari jawaban dari beberapa poin berikut: Pertama, pengertian atau definisi dari konsep fiqh keindonesiaan; Kedua, tokoh-tokoh penggagas fiqh keindonesiaan dan hasil pemikirannya; dan Ketiga, formalisasi konsep fiqh yang bernuansa keindonesiaan tersebut ke dalam tata hukum di Indonesia. Penelitian ini adalah penelitian pustaka atau library research dengan metode content analysis. Adapun hasil penelitian ini adalah; (1) Fiqh Keindonesiaan dapat diartikan sebagai sebuah konsep fiqh yang lebih berbasis lokal Indonesia; (2) Hasbi As-Shiddiqi dan Hazairin merupakan dua tokoh penggagas fiqh model keindonesiaan tersebut, selain para cendikiawan lainnya. Hasbi termasuk salah seorang pembaharu yang menawarkan ide-idenya secara komprehensif, mulai dari konsep "fiqh Indonesia"-nya, sampai pembaharuan hukum yang meliputi prinsip dan sekaligus metodenya. Sedangkan Hazairin mengusulkan pengembangan suatu sistem warisan baru yang diinterpretasikan dan dielaborasikan berdasarkan persepsi skriptual al-Qur'an dan Sunnah bukanlah sistem patrilineal, tetapi bilateral, yakni model kekeluargaan; dan (3) Formalisasi konsep fiqh yang bernuansa keindonesiaan telah menghasilkan beberapa produk peraturan perundang-undangan penting yang secara formil maupun material, seperti UU tentang Hukum Perkawinan Islam, juga terdapat peraturanperaturan lain yang berada di bawah Undang-undang, Seperti PP, Inpres dan Peraturan Mahkamah Agung, dan Kompilasi Hukum Islam dan Kompilasi Hukum Ekonomi Syariah.
\end{abstract}

Kata Kunci : Pembaharuan Hukum Islam, Fiqh Keindonesiaan, Formalisasi, Hukum Nasional 


\section{PENDAHULUAN}

Ketika singgah di Samudra Pasai pada tahun 1345 Masehi, Ibn Batutah, seorang pengembara, mengagumi perkembangan Islam di negeri tersebut. Ia mengagumi kemampuan sultan Malik al-Zahir dan berdiskusi tentang berbagai masalah Islam dan ilmu fiqih. Menurut pengembara Arab Islam asal Maroko itu, selain sebagai seorang raja, Malik al-Zahir yang menjadi sultan Pasai ketika itu juga seorang ulama yang ahli di bidang hukum Islam. Adapun mazhab yang dianut kerajaan Pasai waktu itu adalah mazhab Syafi' i. ${ }^{1}$ Menurut Hamka, dari Pasailah disebarkan paham Syafi'i ke kerajaan-kerajaan Islam lainnya di Indonesia. Bahkan setelah kerajaan Islam Malaka berdiri (1400-1500 Masehi) para ahli hukum Islam Malaka datang ke Samudra Pasai untuk meminta fatwa berbagai masalah hukum Islam yang terjadi dalam masyarakat mereka. ${ }^{2}$

Dalam proses Islamisasi kepulauan Indonesia yang dilakukan oleh para saudagar melalui perdagangan dan perkawinan, peranan hukum Islam adalah besar. Ini dapat dilihat dari kenyataan bahwa kalau seorang saudagar muslim hendak menikah dengan seorang wanita pribumi, maka wanita tersebut diislamkan lebih dahulu dan pernikahannya dilaksanakan sesuai hukum Islam. Keluarga yang tumbuh dari pernikahan inipun mengatur hubungan antara anggota keluarganya berdasarkan kaidah hukum Islam, kalau salah seorang keluarganya meninggal, harta waris dibagi menurut ketentuan hukum Islam. ${ }^{3}$

Setelah agama Islam berakar dalam masyarakat, peranan saudagar dalam peyebaran Islam digantikan oleh para ulama yang bertindak sebagai guru dan pengawal hukum Islam. Misalnya nama Nuruddin al-Raniri (ulama yang hidup pada abad ke-17) menulis buku hukum Islam dengan judul Sirath al-Mustaqîm pada tahun 1628 Masehi. Menurut Hamka, kitab yang ditulis al-Raniri ini merupakan kitab hukum Islam pertama yang disebarkan ke seluruh Indonesia. Oleh Syeikh Muhammad Arsyad al-Banjari, yang menjadi mufti di Kerajaan Banjar, kitab tersebut diperpanjang uraiannya dan dijadikan pegangan untuk menyelesaikan sengketa antar umat Islam di Banjarmasin, kitab tersebut dinamakan Sabilul Muhtadin. Di daerah kesultanan Palembang dan Banten terbit pula beberapa kitab hukum Islam yang dijadikan pegangan umat Islam, misalnya kitab fiqih yang bernama Fathul Qarib yang ditulis oleh Syeikh Nawawi al-Bantani. ${ }^{4}$

Hukum Islam diikuti dan dilaksanakan juga oleh para pemeluk agama Islam dalam kerajaan-kerajaan di pulau Jawa seperti Demak, Jepara, Tuban, Gresik, Ngampel dan kemudian Mataram. ${ }^{5}$ Demikianlah sejak berabad-abad lamanya hukum Islam telah dikenal di kepulauan Indonesia sewaktu Indonesia masih berbentuk kerajaan-kerajaan kecil, sebelum Indonesia menjadi negara kesatuan.

Ketika negeri-negeri lain sejak akhir abad ke-19 mengalami modernisasi dalam banyak bidang kehidupan, bangsa Indonesia berada dalam kondisi dan kungkungan tradisionalisme atau kejumudan. Berbagai kondisi buruk akibat penjajahan seperti kemiskinan, kebodohan, ketertindasan, keterbelakangan, semuanya menyatu dengan alam pikiran tradisi yang melahirkan sikap statis (jumud, status-quo), menyerah pada nasib (fatalistik), dan diliputi pandangan hidup serba mitos (mitologis). ${ }^{6}$

Umat Islam Indonesia meskipun secara formal menganut Islam tetapi jauh dari sumber ajaran yang asli atau murni, yaitu al-Qur'an dan Sunnah yang shahih atau maqbullah. Praktik Islam yang bersifat syirk (menyekutukan Allah), tahayul (percaya pada hal-hal gaib yang tidak

${ }^{1}$ Saifuddin Zuhri, Sejarah Kebangkitan Islam dan Perkembangannya di Indonesia, Bandung: Al-Ma'arif, 1979, h. 204-205.

2 Hamka, Antara Fakta dan Khayal “Tuanku Rao”, Jakarta: Bulan Bintang, 1974, h. 53.

3 M. Naquib Al-Attas, Islam and Secularizm, Kuala Lumpur: Abim, 1978, Bandung: Pustaka, 1981, h. 247.

${ }_{5}^{4}$ Hamka, Antara Fakta dan Khayal "Tuanku Rao", Jakarta: Bulan Bintang, 1974, h. 323.

5 Muhammad Daud Ali, Hukum Islam: Pengantar Ilmu Hukum dan Hukum Islam Indonesia, Jakarta: PT Raja Grafindo Persada, 2007, h. 234.

${ }^{6}$ Haidar Nashir, Muhammadiyah Gerakan Pembaharuan, Yogyakarta: Suara Muhammadiyah, 2010, h.62. 
perlu), khurafat (percaya pada tanda-tanda alam yang dikaitkan dengan nasib hidup), dan bid'ah (mengada-ada ajaran yang tidak ada contohnya dari Nabi atau ajaran Islam yang murni) berkembang dalam kehidupan umat Islam Indonesia pada masa ini. Modernisasi dipandang sebagai produk Barat yang harus dijauhi, karena saat itu umat Islam menganut pandangan "tasyabuh", yakni siapa yang menyerupai suatu kaum maka sama dengan kaum tersebut (man tasyabaha bi qaumin fa huwa minhum). Jadi, pemahaman masyarakat muslim Indonesia ketika itu, siapapun yang mengikuti modernisme maka ia sama dengan orang-orang Barat yang kafir. Karena cara berpikir seperti itulah yang menjadikan umat Islam Indonesia semakin tertinggal dan terbelakang dibandingkan dengan bangsa-bangsa yang lain pada masanya.

Ditengah kondisi tertinggal dan terbelakang itulah kemudian di awal abad ke-20 lahir gerakan-gerakan pembaharuan Islam modern di dunia Islam, termasuk di Indonesia. Umat Islam di Indonesia (karena mendapat pengaruh dari gema kebangkitan Islam di seluruh penjuru dunia) tidak tinggal diam menghadapi kejumudan ini. Karena itu kemudian mucul gerakangerakan Islam yang bersama kekuatan bangsa yang lain bangkit melawan penjajahan melalui gerakan modernisme atau reformisme Islam. Gerakan tersebut ingin melakukan pembaharuan dalam segala aspek kehidupan menuju pada kemajuan dan kejayaan umat Islam di Indonesia, terutama pembaharuan fiqh Islam konvensional yang kelahirannya erat dipengaruhi oleh situasi dan kondisi penulisnya, yang mana mayoritas adalah bangsa Arab. Sehingga ketika hukum Islam dalam kitab-kitab fiqh tersebut hendak diterapkan umat Islam di nusantara, tidak berjalan sebagaimana di negara-negara Arab. Hal itu dapat dimaklumi karena adanya perbedaan budaya dan adat antara masyarakat nusantara dengan bangsa Arab. Sehingga yang terpenting dalam konsep pembaharuan hukum Islam di Indonesia adalah bagaimana hukum Islam dapat diaktualisasikan dalam kehidupan umat Islam Indonesia dengan cara mengakulturasikan hukum Islam sesuai dengan kebutuhan masyarakat di Indonesia.

Penelitian ini dimaksudkan untuk memahami secara utuh ide pembaharuan hukum Islam di Indonesia hingga lahirnya istilah fiqh keindonesiaan. Karena itu perlu diajukan beberapa poin masalah yang hendak ditemukan jawabannya dalam penelitian ini, yakni: Pertama, pengertian atau definisi dari konsep fiqh keindonesiaan; Kedua, tokoh-tokoh penggagas fiqh keindonesiaan dan hasil pemikirannya; dan Ketiga, formalisasi konsep fiqh yang bernuansa keindonesiaan tersebut ke dalam tata hukum di Indonesia. Penelitian ini adalah penelitian pustaka atau library research dengan metode content analysis. Adapun hasil yang diharapkan dari penelitian ini adalah selain untuk menjawab pertanyaan-pertanyaan pada lingkup kajian di atas, juga untuk membuktikan lebih jauh bahwa hukum Islam adalah hukum yang berorientasi pada kemaslahatan, sehingga harus diwujudkan dalam sifatnya yang elastis, sesuai dengan kemaslahatan yang dibutuhkan oleh zaman, tempat, dan kondisi yang melingkupinya.

\section{PEMBAHASAN}

\section{Sekilas Teori Pembaharuan Hukum Islam}

Beberapa ahli hukum Islam dari Barat telah mengkaji secara serius perkembangan dan pembaharuan hukum Islam yang terjadi di beberapa negara dewasa ini. Anderson, salah seorang peneliti hukum Islam, menyimpulkan adanya beberapa poin penting dalam proses pembaharuan di beberapa negara. ${ }^{7}$ Diantaranya, sejak kira-kira tahun 1850 terjadi dikotomi hukum dalam dunia Islam; satu bagian diwarnai oleh aturan-aturan yang khas berinspirasi Barat, seperti hukum dagang, sementara bagian lainnya tetap berada di bawah naungan syari'ah, seperti hukum keluarga. Berikutnnya sejak tahun 1915 proses perubahan hukum keluarga itu berkembang dengan pesat.

Pembaharuan di sini dilaksanakan dengan tiga bahan pokok, yaitu (a) adanya sarana untuk memperoleh pengakuan berlakunya hukum atas tuntutan-tuntutan yang diajukan oleh

7 J.N.D. Anderson, Islamic Law in the Modern World, Connecticut: Greenwood Press, 1975, hh. 109-111. 
syari'ah. (b) Prinsip yang mengatakan bahwa sebagai pengganti pelaksanaan pandanganpandangan dominan dari mazhab tertentu, seperti dari mazhab Hanafi, mengenai persoalan yang rinci (furû'). Di sini badan legislatif diperbolehkan menerapkan variasi tertentu dari pandangan-pandangan tersebut, seperti yang dikemukakan oleh beberapa mazhab lain dan (c) diperlakukannya aturan-aturan hukum acara untuk melengkapi syari'ah yang pelaksanaannya disertai dengan sanksi-sanksi pidana.

Sedangkan Coulson mengklasifikasikan pembaharuan hukum Islam ke dalam empat bentuk; Pertama, adanya upaya kodifikasi hukum Islam menjadi undang-undang hukum negara; sejumlah hukum Islam di-ijtihâd-kan sebagai hukum negara, sehingga memiliki kekuatan hukum yang mengikat bagi warga negara dan memiliki sanksi bagi pelanggarnya. Ini disebut prinsip siyâsah. Kedua, munculnya prinsip takhayyur yaitu kaum muslimin bebas memilih pendapat para imam mazhab dan menggunakannya sesuai dengan kemaslahatan masyarakat. Ketiga, munculnya upaya untuk mengantisipasi perkembangan peristiwa hukum yang baru dengan mencari alternatif-alternatif hukum dengan menggunakan prinsip-prinsip hukum Islam yang luwes dan elastis. Prinsip ini disebut prinsip tathbîq. Keempat, timbulnya upaya perubahan hukum dari yang lama kepada yang baru, sesuai dengan perkembangan masyarakat yang bersifat dinamis yang disebut konsep tajdîd (neo-ijtihâd). ${ }^{8}$

Sementara menurut analisis Abdullahi Ahmad an-Na'im (Na'im, 1997:74), pembaharuan hukum keluarga dan waris Islam di beberapa negara mengambil beberapa teknik, yaitu takhayyur dan siyâsah, seperti penjelasan Coulson tersebut. ${ }^{9}$ Namun, ia menambahkan tiga bentuk yang lain, yaitu, pertama, takhsîsh al-Qadha atau hak penguasa untuk memutuskan dan menguatkan keputusan pengadilan. Ini digunakan sebagai prosedur untuk membatasi penerapan syari'ah pada persoalan-persoalan hukum perdata. Prosedur yang sama juga digunakan untuk mencegah pengadilan dari penerapan syari'ah dalam keadaan yang spesifik tanpa mengubah substansi aturan-aturan syari'ah yang relevan. Kedua, reinterpretasi atas ketentuan-ketentuan hukum yang berlaku, misalnya dalam Hukum Status Personal Tunisia Tahun 1956 dinyatakan bahwa perceraian tidak sah kecuali dengan keputusan pengadilan. Ketiga, pembaharuan dilakukan dengan cara yang digunakan dalam tradisi hukum adat tanpa menentang dan mengubah prinsip dan aturan-aturan syari'ah yang berdasarkan al-Qurân dan hadis seperti yang terjadi di India. ${ }^{10}$ Adapun di Indonesia, dalam upayanya melakukan reinterpretasi hukum Islam yang telah ada, demi membangun mazhab fiqh nasional, sedikit banyak menganut prinsip-prinsip yang dijelaskan tersebut.

\section{Fiqh Keindonesiaan: Sebuah Gerakan Pembaharuan Hukum Islam}

Terdapat beberapa definisi tentang apa yang disebut sebagai fiqh keindonesiaan. Namun demikian, Definisi yang menurut penulis paling proporsional adalah apa yang dipahami oleh penggagasnya, yakni Hasbi as-Shiddiqi sebagai "fiqh yang ditentukan berdasarkan kepribadian dan karakter bangsa Indonesia". ${ }^{11}$

Gerakan pembaharuan hukum Islam yang muncul di Indonesia pada akhir abad ke-19. Lokomotif utamanya diantaranya adalah A. Hasan, seorang tokoh PERSIS yang menyerukan pentingnya umat Islam di Indonesia kembali kepada al-Qur'an dan Sunnah. Selain A. Hasan, muncul pula gerakan pembaharuan dengan model yang sama, yaitu Muhammadiyah. Paham keagamaaan Muhammadiyah selalu mengaitkan dan mempertautkan dimensi ajaran ke sumber al-Qur'an dan Sunnah yang shahih dengan dimensi ijtihad dan tauhid dalam satu kesatuan yang utuh. Melalui Majelis Tarjihnya, Muhammadiyah merespon berbagai persoalan

8 N.J. Coulson, A History of Islamic Law, Edinburgh: Edinburgh University Press, 1971, hh. 182-217.

9 Abdullah Ahmad An-Na'im, Dekonstruksi Syari'ah, terj. A. Suaedi dan Amiruddin, Yogyakarta: LkiS, 1997, h. 74.

${ }^{10}$ Ibid.

${ }^{11}$ Hasbi Ash Shiddieqy, Syari'at Islam Menjawab Tantangan Zaman, (Yogyakarta : IAIN Sunan Kalijaga, 1961), h. 
keagamaan dengan kacamata fiqih yang normatif dan dianggap tidak menghargai nilai dan budaya lokal. Bahkan Muhammadiyah sendiri cenderung terjebak pada klaim kebenaran dan terkesan terburu-buru dalam memberi label bid'ah kepada aktifitas keagamaan yang dilakukan kelompok Islam tradisional. Sehingga ajaran Muhammadiyah tidak banyak diikuti oleh mayoritas umat Islam di Indonesia. Sementara solusi dari permasalahan yang ditawarkan oleh Muhammadiyah masih memerlukan elaborasi dan interpretasi dari referensi normatif AlQur'an dan Hadis. ${ }^{12}$ Namun sebagaimana A. Hasan, paham keagamaan Muhammadiyah juga mendapat tantangan yang cukup keras dari kelompok Islam tradisional. Tidak seperti A. Hasan dan Muhammadiyah yang ide pembaharuannya mendapat banyak tantangan, Hasbi As-Siddiqi tidaklah demikian. Idenya tidak dirilis dengan cara menyerang praktek-praktek hukum Islam yang telah established, tapi disampaikan dalam frame yang lebih bersifat dialogis. Disamping itu, menurut penulis, Hasbi termasuk salah seorang pembaharu yang menawarkan ide-idenya secara komprehensif, mulai dari konsep "fiqh Indonesia"-nya, sampai pembaharuan hukum yang meliputi prinsip dan sekaligus metodenya.

Ide pembaharuan hukumnya sebagian mulai masuk dalam diskursus hukum Islam di Indonesia pada tahun 1940 dan kemudian diulangi lagi pada tahun 1961. Gagasan utamanya adalah pentingnya formulasi fiqh Indonesia. Menurut Hasbi, fiqh Indonesia adalah fiqh yang sesuai dengan budaya dan karakter masyarakat Indonesia. Artinya fiqh yang berkepribadian Indonesia. Menurut pengamatannya, jika fiqh diharapkan bisa dipakai dan memasyarakat di Indonesia, maka ia bukan saja harus mampu memecahkan persoalan-persoalan yang timbul dalam masyarakat dengan adil dan mashlahah, tapi fiqh juga harus mudah dipahami dan tidak asing. Menurutnya fiqh yang berkepribadian Indonesia dapat diwujudkan. Jika 'urf di Arab bisa menjadi sumber fiqh yang berlaku di Arab, maka 'urf Indonesia tentunya juga bisa menjadi sumber hukum yang bisa ditetapkan di Indonesia. ${ }^{13}$

Semangat pembaharuan fiqih di Indonesia ini kemudian diikuti oleh Hazairin yang pada awal tahun 1950-an menawarkan konsep "Mazhab Nasional", walaupun bertulang punggung mazhab Syafi'i, tetapi mazhab nasional membatasi ruang lingkupnya pada hukumhukum non-ibadah yang belum dijadikan undang-undang oleh negara. ${ }^{14}$ Pada awal tahun $1960-$ an, datangnya para sarjana muslim Nusantara yang belajar di Universitas-universitas Barat serta Timur Tengah turut mewarnai dinamika hukum Islam (fiqih) di Indonesia. Kebanyakan para sarjana tersebut berpikiran rasional. Pemahaman fiqih yang mereka kemukakan tampak berbeda dari dua corak yang telah ada, namun ide-ide pembaharuan yang mereka lontarkan lebih kental dengan nuansa keindonesiaan. Inilah masa dimana pembaharuan pemikiran Islam terjadi baik dalam bidang kajian studi ilmu-ilmu tafsir, hadis, fiqih, tasawuf, dan sebagainya. Tokoh-tokoh yang muncul pada era ini diantaranya Pada tahun 1987, Munawir menawarkan kaji ulang terhadap interpretasi hukum Islam, dengan menekankan pada perubahan 'urf, maslahat, dan mafsadat - yang populer sebagai "Reaktualisasi hukum Islam"walau Munawir menyebutnya "Dinamika Hukum Islam". ${ }^{15}$ Di tahun yang sama, Abdurrahman Wahid (Gus Dur) mengemukakan gagasan "Pribumisasi Islam" dan Masdar F. Mas'udi menawarkan konsep "Zakat sebagai Pajak". ${ }^{16}$ Jauh sebelum teori-teori keindonesiaan hukum Islam ini

\footnotetext{
${ }^{12}$ Lihat Ahmad Zain An-Najah, makalah Majlis Tarjih Muhammadiyah Pengenalan, :Penyempurnaan Dan Pengembangan, Kairo : 2004.

${ }^{13}$ Lihat pemikiran Hasbi as-Shiddiqi dalam karya-karyanya berikut: Syari'at Islam Menjawab Tantangan Zaman. Yogyakarta : IAIN Sunan Kalijaga, 1961, Dinamika dan Elastisitas Hukum Islam. Jakarta : Tintamas, 1975, dan Beberapa Permasalahan Hukum Islam. Jakarta : Tintamas, 1975.

${ }^{14}$ Hazairin, Hukum Kewarganegaraan Nasional, edisi ke-3, (Jakarta

Tintamas, 1982), h. 6.

15 Munawir Sjadzali, Reaktualisasi Ajaran Islam, dalam Polemik Reaktualisasi Ajaran Islam, ed., Iqbal Abdurrauf Sainima, (Jakarta : Pustaka Panjimas, 1980), h.1.

${ }^{16}$ Masdar F. Mas'udi, Agama Keadilan :Risalah Zakat (pajak) dalam Islam, edisi ke-3, (Jakarta : P3M, 1993).
} 
muncul, pada tahun 1940, Hasbi telah mengemukakan gagasan tentang perlunya pembentukan "Fiqh Indonesia", yang pada tahun 1961 ia definisikan sebagai "fiqh yang ditentukan berdasarkan kepribadian dan karakter bangsa Indonesia". ${ }^{17}$

Dalam kurun waktu yang relatif sama muncul pula para pembaharu Islam dengan pemikiran yang bercorak rasional keindonesiaan seperti Harun Nasution, Nurkholis Madjid, Quraish Shihab, Sa'id Aqil Siraj, dan lainnya, yang menyerukan pentingnya reinterpretasi ajaran agama Islam dengan fungsionalisasi akal secara proporsional. Menurut pandangan para pembaharu modern tersebut, cara berpikir tekstual-tradisional - yaitu menempatkan teks alQur'an dan Sunnah sebagai pijakan utama dalam menentukan segala aktivitas kehidupannya tanpa memberikan porsi yang lebih luas kepada peran akal - tidak akan mampu menjawab permasalahan umat Islam modern, apalagi permasalahan pada umat Islam yang sama sekali berbeda kultur dan adatnya dari bangsa Arab, tentunya tidak bisa diselesaikan dengan cara berpikir tradisionalis-konservatif. Ketentuan-ketentuan teks al-Qur'an dan Sunnah yang jelas dan rinci, dan kitab-kitab karya para ahli hukum Islam tradisionalditerima tanpa interpretasi ulang diyakini tidak akan mampu memberikan solusi yang memadai dalam menjawab realitas konkret saat ini. ${ }^{18}$ Sehingga dengan demikian, pembaharuan hukum Islam yang bercorak rasional keindonesiaan merupakan suatu keniscayaan.

Di antara sarjana penggagas fiqih yang bercorak rasional keindonesiaan kontemporer adalah M. Quraish Shihab. Telah banyak sekali fatwa-fatwa hasil ijtihad Quraish Shihab - baik yang dituangkan dalam karya besarnya Tafsir Al-Misbah, maupun dalam buku-bukunya yang lain - yang berbeda dengan hukum fiqih yang telah ada sehingga dianggap kontraversial seperti kebolehan bagi umat Islam mengucapkan selamat Natal kepada kaum Nasrani dengan syarat tidak tercemar aqidahnya, ${ }^{19}$ juga fatwa-fatwa lainnya dalam masalah fiqih wanita, misalnya pendapatnya tentang tidak wajibnya bagi wanita Indonesia memakai jilbab, ${ }^{20}$ serta poligami tidak dianjurkan apalagi diwajibkan. ${ }^{21}$

Pemikiran-pemikiran para cendikiawan dan ulama Indonesia tersebut, tentunya berbeda dengan apa yang telah tertulis dalam kitab-kitab fiqh konvensional klasik. Namun tentunya sebagai hasil karya para ulama dan intelektual asli Indonesia, pemikiran hukum Islam tersebut merupakan hasil dari renungan dan dilakukan dengan metodologi ilmiah yang dapat dipertanggungjawabkan secara akademis. Pemikiran-pemikiran tersebut di atas - yang oleh penulis dianggap sebagai corak pemikiran fiqh Indonesia - terlahir tidak tanpa sebab. Sebagaimana fiqh konvensional, kelahirannya tentu sangat dipengaruhi oleh banyak faktor, termasuk faktor kondisi lingkungan adat-istiadat yang menyertai pemikirnya. Sehingga fiqh tidaklah harus disakralkan, karena pada dasarnya fiqh merupakan bentuk pemahaman para ulama yang dari sisi kebenarannya bersifat relatif. Karenanya, tidak seharusnya fiqh yang bercorak kearaban dipaksakan untuk diaplikasikan dimasyarakat tertentu yang berbeda seperti umat Islam di kepulaian nusantara.

Kaum reformis hukum Islam di Indonesia bercita-cita ingin membangun hukum Islam yang indegenous keindonesiaan. Mereka berusaha membebaskan adat Indonesia dari adat Arab karena menurut mereka, Islam tidak berarti Arab. Di samping itu, perbedaan adat ini sangat dipengaruhi oleh realita bahwa posisi Indonesia terletak di pinggiran bukan di tengah-tengah dunia Islam. Tentu saja ruang gerak ijtihâd yang di-ijtihâd-ikan sarana untuk mewujudkan hukum Islam ala Indonesia ini tidak memasuki wilayah ibadah.

${ }^{17}$ Hasbi Ash Shiddieqy, Syari'at Islam Menjawab Tantangan Zaman, (Yogyakarta : IAIN Sunan Kalijaga, 1961), h. 24.

18 Abdullah Ahmad An-Na'im. Shari'a and Islamic Family Law: Transition and Transformation. (New York: Emory University, 2002). h. 20.

${ }^{19}$ Quraish Shihab. Membumikan Al-Qur'an. (Jakarta : Mizan, cet. Ke-18, 1994 ). h. 370.

${ }^{20}$ Penjelasan selengkapnya dapat dibaca di buku karangan Quraish Shihab yang berjudul Jilbab, Pakaian Wanita Muslimah. (Jakarta: Lentera Hati, 2004).

${ }^{21}$ Lihat buku Quraish Shihab, Perempuan. (Jakarta: Lentera Hati, 2005). h. 165-166. 


\section{Hasbi As-Siddiqi, Penggagas Fiqh Keindonesiaan}

Gerakan Hasbi dalam menciptakan suatu madzhab Indonesia menandai perubahan signifikan dalam pemikirannya, dan secara umum, dalam perkembangan Islam Indonesia. Meskipun pada awalnya dia tertarik terhadap reformisme skriptualis dari PERSIS, namun kemudian ia meninggalkannya. Baik A. Hassan (juru bicara PERSIS yang cukup terkenal) dan Hasbi membuka kembali upaya ijtihâd, tetapi mereka memahami istilah tersebut dengan cara yang berbeda. A. Hassan dan sebagian besar koleganya di PERSIS, secara khusus memahami ijtihâd sebagai suatu upaya dimana (kesalahan) interpretasi ([mis]interpretation) masa lalu terhadap hukum dapat diidentifikasi dan dieliminasi dalam proses "kembali pada Qur'an dan Sunnah," dengan meminjam istilah Moenawar Chalil. ${ }^{22}$ Hasbi memperkenalkan relevansi jenis ijtihâd ini, tetapi hanya sebagai langkah awal dari reformulasi hukum Islam. Dia mengemukakan bahwa setelah kemurnian hukum dan ajaran otentik dari al-Qur'an dan Sunnah dikembangkan, maka ia menjadi tanggung jawab dari mujtahid untuk membuat hukum-hukum dan ajaran tersebut secara langsung lebih relevan terhadap kehidupan umat Islam yang hidup dalam masyarakatnya.

Bagi Hasbi, purifikasi doktrin beragama dan hukum hanya merupakan langkah awal dalam proses penentuan agar hukum lebih sesuai dengan situasi kontemporer. Dari penjelasan tersebut, secara kontekstual merupakan hal yang penting untuk mengaplikasikan hukum pada kondisi kontemporer yang berarti "mengindonesiakan" (Indonesianizing) wacana tentang jurisprudensi Islam. Hasbi mengupayakan hal ini melalui sebuah penegasan terhadap suatu pemahaman hubungan antara adat dan hukum Islam yang lebih memandang keduanya sebagai hubungan komplementer daripada hubungan antagonistik. ${ }^{23}$

Kajian-kajiannya tentang persoalan ini, dalam banyak hal mengingatkan kembali pada figur kontemporer Mesir, 'Abdul Wahab al-Khallaf (w. 1956). Namun demikian, bukan berarti bahwa Hasbi begitu saja mengambil 'batu dari bangunan modernisme Mesir'. Justru dia lebih aktif dan selektif dalam menentukan aspek-aspek khusus dari tujuan Indonesia yang baru dan berbeda yaitu penciptaan 'pendidikan hukum nasional.' Penggunaan kontekstualisasi budaya lokal dalam interpretasi dan aplikasi ajaran skriptural 'murni' merepresentasikan sesuatu yang baru sebagaimana secara sadar yang dipahami tidak hanya sekedar sebagai langkah lain terhadap reformasi hukum Islam tanpa henti, tetapi sebagai suatu upaya kreatif nasional untuk menginstitusi metodologi hukum baru tentang pijakan metode fiqih yang dikembangkan.

Hasbi memimpikan formulasi dan aplikasi fiqih baru Indonesia yang dilakukan melalui suatu proses ijtihâd kolektif yang direformulasi. Dia mengelaborasikan gagasan ini dengan kajian ijma', dan dalam konteks perdebatan seputar dasar hubungan Islam dan Negara Indonesia. Disana Hasbi membedakan antara ijma' masyarakat Islam awal dan yang dilakukan saat ini. Dia menegaskan bahwa keputusan terdahulu didasarkan pada konsensus yang seharusnya ditelaah ulang dan bahwa keputusan-keputusan baru yang secara hukum terikat dapat terus dimunculkan melalui sebuah lembaga legislator. Dalam hal ini, dia mengkombinasikan pemahaman nasionalisnya tentang ijtihâd dengan reformulasi kontemporer tentang syura, yang berharap mampu mengembangkan wilayah yang jelas untuk hukum Islam dalam negara Indonesia modern.

Hasbi mendasarkan argumentasi-argumentasi umumnya tentang penciptaan sebuah sistem fiqih Indonesia pada hasil telaahnya terhadap sejarah hukum Islam dan perkembangannya di abad-abad awal Islam. Dia menegaskan bahwa berdasarkan konteks dimana hukum itu berkembang, elemen-elemen budaya Arab dan Timur Tengah mengembangkan penciptaan sistem fiqih dengan teori hukum klasik. Secara singkat dia

${ }^{22}$ Michael Feener, Gerakan Indonesia Menuju Mazhab Nasional, Jurnal Ulumuddin, Volume IV, Tahun III, Januari-Juni 2009.

${ }^{23}$ Ibid. 
menegaskan bahwa banyak hal yang secara tradisional dianggap 'hukum Islam' seharusnya dianggap sebagai "fiqih Arab". ${ }^{24}$ Hasbi mengakui bahwa kondisi kontemporer dimana umat Islam Indonesia tinggal menyisakan banyak pertanyaan baru, dan membutuhkan jawabanjawaban baru dari pertanyaan-pertanyaan lama, sehingga perlu suatu pendekatan baru dan lebih relevan dalam mengkaji persoalan fiqih. Karenanya ia mencoba menemukan cara-cara dimana aturan hukum dan moral al-Qur'an menjadi relevan terhadap kondisi dan persoalan kontemporer. Dalam hal ini, orang mungkin mengemukakan tentang gerakan dua arah (bidirectional) dalam pendekatan Hasbi: Pertama, mengembalikan pada sumber asli untuk menentukan pesan penting mengenai hukum; Kedua, menyesuaikan dengan situasi kontemporer untuk menentukan interpretasi dan aplikasi aturan skriptural yang sesuai terhadap kondisi dan persoalan tertentu. Disini orang mendapati sebuah isyarat pendekatan Fazlur Rahman yang mendapatkan tempat penting dalam pemikiran Islam Indonesia.

Untuk menjustifikasi lokalitas fiqh Indonesia, Hasbi berpegang pada sejarah perkembangan fiqh (tarikh tasyri'). Tarikh tasyri', menurut Hasbi membuktikan bahwa fiqh lokal telah muncul sejak awal penyebaran Islam melawati batas-batas Mekkah dan Madinah. Mazhab Hanafi di Kufah, Maliki di Madinah, Syafi'i di Baghdad (mazhab qadim) dan kemudian di Mesir (mazhab jadid), di samping mazhab Hanbali di Baghdad, tentunya merupakan bagian dari contoh yang populer. Lokalitas mazhab-mazhab ini menurut Hasbi, dikarenakan perbedaan pendapat, tempat, adat istiadat dan jiwa mujtahid sendiri. ${ }^{25}$

Sistem hukum yang dianut Hasbi berpijak pada prinsip mashlahah mursalah yang berdasarkan keadilan dan kemanfaatan serta sad al-dzâri'ah. Ia berpendapat prinsip yang merupakan gabungan dari prinsip-prinsip yang dipegang para imam mazhab ini, khususnya aliran Madinah dan Kufah, mampu membawa ketertiban dan kesejahteraan dalam masyarakat serta akan memberikan ruang gerak yang lebih luas bagi dilakukannya ijtihad-ijtihad baru. Dalam penggalian hukum, Hasbi menggunakan metode analogi deduksi yang memberi kebebasan ber-ijtihad seperti yang dipakai oleh Abu Hanifah dalam membahas masalahmasalah yang tidak diperintah dan tidak pula dilarang serta yang belum ada ketetapan hukumnya. ${ }^{26}$

Adapun terhadap masalah-masalah yang telah ada ketetapan hukumnya, maka Hasbi memakai metode komparasi, yakni membandingkan antara satu pendapat dengan pendapat yang lain dari seluruh aliran hukum yang ada dan memilih yang lebih baik serta lebih dekat kepada kebenaran dan didukung oleh dalil yang kuat (tarjih). ${ }^{27}$ Dengan demikian, Hasbi menganut sistem berpikir eklektif. Inilah kelebihan Hasbi dibanding dengan pembaharu yang lain.

Studi perbandingan ushul fiqh ini dilakukan dengan tahapan-tahapan sebagai berikut :

a. Mengkaji prinsip-prinsip yang dipegang oleh setiap imam mazhab maupun masalahmasalah yang mereka perselisihkan dengan meneliti alasan-alasan mereka.

b. Mengkaji dalil-dalil yang di-ijtihâdikan rujukan maupun yang diperselisihkan.

c. Mengkaji argumen yang ditawarkan oleh masing-masing imam mazhab mengenai dalildalil yang diperselisihkan dan memilih argumen-argumen yang kuat.

Sebaliknya, jika problem yang dihadapi belum pernah diberikan pemecahannya oleh mujtahid-mujtahid terdahulu, maka dianjurkan agar pendukung fiqh Indonesia melakukan

${ }^{24}$ Muhammad Atho Mudzhar, Fatwa-fatwa Majelis Ulama Indonesia: Sebuah Studi tentang Pemikiran Hukum Islam di Indonesia, 1975-1988.Jakarta: INIS, 1993, h. 374.

${ }^{25}$ Bassam Tibi, Islam and the Cultural Accommodation of Social Change, terj. Clare Krojl, Boulder : Westview Press, 1990, h. 66.

26 Chamim Tohari, Reformulasi fiqh arab menuju fiqh keindonesiaan (telaah sosio-historis dan metodologis, serta formalisasinya sebagai hukum nasional, Jurnal Ulumuddin, Volume IV, Tahun III, Universitas Muhammadiyah Malang, 2009.

27 Ibid. 
ijtihâd bi al-ra'yi, yaitu menentukan hukum berdasarkan pada maslahat, kaidah-kaidah kulliyh dan illat (kausa) hukum, sedangkan metode yang ditempuh adakalanya :

a. Qiyâs yang dilakukan dalam kondisi terpaksa, tidak menyangkut masalah ibadah. Selain qiyâs illat dan qiyâs dalâlah, tidak berlaku.

b. Istihsân dengan berbagai macamnya : istihsân bin nâs, istihsân bil ijtima', istihsân bil qiyâs, istihsân bi ad-darûrâh, istihsân bil maslahah, dan istihsân bil 'urf.

c. Istishlah, dengan ketentuan bahwa sesuatu dapat dinyatakan sebagai maslahat jika merupakan maslahat hakiki; berlaku umum tidak hanya terbatas pada segelintir orang; harus diputuskan oleh ahl al-Hall wa al-'Aqd. Jika maslahah bertentangan dengan nash, maka maslahah mentakhsis (mengkhususkan) nash dengan menjadikan hadits "Lâ dharâra wa lâ dhirâra" sebagai kata kunci di akhir analisa.

d. 'Urf dengan ketentuan tidak menghalalkan barang haram dan tidak mengharamkan barang halal; dapat mendatangkan maslahat dan menghilangkan mafsadat; tidak bertentangan dengan nash sharih (ekspilist); di samping itu harus diputuskan oleh ahl al-Hall wa al'Aqd; atau

e. Istishâb. Metode-metode ini selalu berjalan seiring dengan kaidah-kaidah yang relavan. ${ }^{28}$

Metodologi yang digunakan dalam ijtihad fiqh keindonesiaan sebenarnya tidak jauh berbeda dengan metodologi para ulama sebelumnya, tetapi adanya perbedaan adat dan budaya dimana seorang mujtahid atau pemikir tinggal, tentunya hasil ijtihad pun berbeda sesuai dengan kebutuhan masyarakat tersebut.

\section{Hazairin dan Sistem Kewarisan Bilateral}

Disamping itu, pembaharuan hukum Islam dalam bidang tertentu - dalam hal ini waris juga muncul dari beberapa tokoh. Misalnya apa yang dikemukakan oleh Hazairin dengan konsep hukum "waris bilateral". ${ }^{29}$ Hazairin memiliki pandangan lain tentang sistem keluarga menurut al-Qurân. Pandangan fiqh tersebut menurut penulis didasarkan atas susunan masyarakat Arab yang menurut ilmu antropologi sosial disebut patrilineal, sedangkan pandangan Hazairin didasarkan atas susunan masyarakat al-Qurân, yang menurut ijtihâdnya, adalah masyarakat bilateral.

Meskipun dia dididik dengan latar belakang pendidikan hukum adat Barat, Hazairin mengkombinasikannya dengan kehidupan Muslim modern secara otodidak sebagaimana yang dilakukan oleh Hasbi dan bahkan reformis awal yang berhubungan dengan PERSIS, mereka memiliki perhatian terhadap reformasi Islam dan perannya dalam masyarakat kontemporer. Dalam essay pengantar karyanya tentang hukum kekeluargaan Indonesia, Hazairin mengemukakan bahwa pandangan-pandangannya tentang struktur bilateral hukum warisan Islam secara fundamental didasarkan pada al-Qur'an, dan dimaksudkan sebagai suatu koreksi terhadap model patrilineal yang berlaku yang dikembangkan oleh para ulama Arab sebagaimana yang termaktub dalam kitab-kitab fiqh konvensional. Namun demikian Hazairin tidak membatasi dirinya dalam melakukan penyederhanaan terhadap penafsiran awal dari teks al-Qur'an. Meskipun dia mengkonstruksi sebuah bacaan kontekstual baru terhadap teks yang relevan, akan tetapi tetap diletakkan secara langsung dalam realitas sosial pada masa dan bangsanya.

Berdasarkan hasil kajiannya tentang hukum adat, Hazairin menunjukkan bahwa masyarakat Indonesia secara umum mendasarkan adat warisannya pada tiga model dasar: patrilineal, matrilineal, dan bilateral (atau parental). Dia mengemukakan bahwa mayoritas masyarakat Muslim Indonesia cenderung mendasarkan pada organisasi bilateral. Alasannya, sistem semacam itu merupakan yang terbaik sebagai model untuk sistem hukum warisan Islam yang baru dan satu bagi perkembangan bangsa Indonesia. Ketidaksesuaian antara sistem-sistem semacam itu dengan model patrilineal masyarakat Arab memiliki pengaruh pada awal

\footnotetext{
${ }^{28}$ Ibid.

${ }^{29}$ Hazairin, Hukum Kewarisan Bilateral Menurut Qur'an dan Hadis, Jakarta: tp, 1982.
} 
pembentukan hukum warisan Islam, Hazairin menegaskan bahwa penambahan elemen-elemen tertentu dari hukum adat Arab seharusnya tidak dianggap sebagai bagian dari penemuan hukum, tetapi hanyalah suatu kecelakaan sejarah yang muncul dari ruang dan waktu dimana sang pembawa pesan terakhir Tuhan (God's last messenger) hidup. Dia menegaskan bahwa agar syariah menjadi 'hukum hidup' (living law) yang aktual dalam masyarakat Indonesia, maka ia harus direinterpretasi sesuai dengan kondisi kultur saat itu, dan bukan berdasarkan situasi asing dan secara historis situasinya berlainan. Dia kemudian mengajukan reinterpretasi hukum Islam berdasarkan aturan spesifik, gamblang, dan prinsip-prinsip al-Qur'an dan Sunnah yang lebih umum, sementara secara simultan tetap hati-hati dalam menerapkannya dalam sebuah masyarakat yang menganut struktur sosial parental (atau bilateral). Karena, sebagaimana yang dikemukakan Hazairin hampir di seluruh karyanya, "etika dan hukum artifisial yang tidak bertentangan dengan aksioma umum hukum agama tetap valid (dengan Islam)". ${ }^{30}$ Dengan menggunakan pendekatan relatif dan kontekstual ini, dia mempertahankan suatu perbedaan antara apa yang dia pahami sebagai hukum eternal Qur'an dan Sunnah dan komentar yang secara temporal dan kultural terbatasi oleh penulis-penulis karya-karya fiqih klasik. Apa yang dia usulkan adalah pengembangan suatu sistem warisan baru yang diinterpretasikan dan dielaborasikan berdasarkan persepsi skriptual al-Qur'an dan Sunnah bukanlah sistem patrilineal, tetapi bilateral, yakni model kekeluargaan.

Melalui kajian-kajiannya tentang antropologi budaya dan hukum adat, Hazairin berupaya memahami Qur'an dengan mempertimbangkan kebutuhan dan perhatian khusus umat Islam yang hidup di Indonesia. Dalam mengusulkan agenda ijtihâd-nya, Hazairin mengelaborasi suatu kritik taqlid, yang dia definisikan, dan kemudian menjadi polemik, sebagai 'imitasi buta' tanpa landasan skriptual yang kuat dan kepatuhan terhadap kebiasaan Arab dengan mengikuti hukum Islam. Sebuah refleksi tentang pendidikan khususnya dalam bidang hukum adat dan pembedaannya antara agama dan adat.

Karenanya jelas bahwa hukum Qur'an dapat ditelaah dari setiap sudut dunia Muslim tanpa harus membuat setiap individu meniru masyarakat Arab, selama umat Islam mampu membebaskan diri mereka dari belenggu taqlid yang mengikatkan diri mereka kepada ulama tradisional dan praktek-praktek sosial Arab ratusan tahun yang lalu dan kembali kepada praktek ijtihâd yang mereka lakukan sendiri. Melalui hal ini, mereka barangkali mereinterpretasi prinsip-prinsip dan hukum-hukum agama yang terkandung dalam Qur'an dan Sunnah, dan kemudian mempersatukan masyarakat dan zaman mereka sendiri dengan persepsi-persepsi mereka yang mulia.

Ide pembaharuan dalam bidang waris juga datang dari mantan Menteri Agama Munawir Sadzali. Idenya terkenal dengan istilah "Reaktulisasi Ajaran Islam”. Ini berawal dari pernyataan dia bahwa umat Islam di Indonesia memiliki sikap ambiguitas dalam beragama, terutama berkaitan dengan hukum Islam. Dia mencontohkan umat Islam bersikap mendua dalam dua hal, yaitu dalam hal bunga bank dan pembagian warisan. Kebanyakan umat Islam masih menganggap bunga bank itu riba, tetapi mereka juga terlibat dalam transaksi-transaksi dengan perbankan yang memakai sistem konvensional ini. ${ }^{31}$

Sedangkan dalam masalah warisan, mereka masih memegang teguh pendirian bahwa perbandingan perolehan harta warisan antara anak laki-laki dan perempuan adalah 2 (dua) dibanding 1 (satu). Akan tetapi, menurut laporan yang dia terima sebagai Menteri Agama saat itu, dalam prakteknya ketentuan ini sering dilanggar, kasus ini terjadi di daerah yang Islamnya terkenal cukup kental seperti di Sulawesi Selatan dan Kalimantan Selatan. Di kedua daerah itu ketentuan fara'id banyak yang tidak berlaku, sebaliknya mereka membawa kasus harta warisan

\footnotetext{
${ }^{30}$ Hazairin, Hukum Kewarganegaraan Nasional, Jakarta: Tintamas, 1982, h. 74.

31 Lihat selengkapnya pemikiran Munawir Sjadzali dalam bukunya, Reaktualisasi Ajaran Islam, dalam Polemik Reaktualisasi Ajaran Islam, ed., Iqbal Abdurrauf Sainima, Jakarta : Pustaka Panjimas, 1980.
} 
ke Pengadilan Negeri. Ada juga pembagian waris dengan mengambil langkah preventif, yaitu dibagikan sebelum pewaris meninggal dunia. ${ }^{32}$

Ada lima ciri menonjol dari paradigma baru itu. Pertama, selalu diupayakan interpretasi ulang dalam mengkaji teks-teks fiqh untuk mencari konteksnya yang baru. Kedua, bermazhab secara metodologis. Ketiga, verifikasi mendasar atas ajaran yang pokok dengan cabang. Keempat, fiqh dihadirkan sebagai etika sosial, bukan sebagai hukum positif negara. Kelima, pengenalan metodologi pemikiran fisolofis, terutama dalam masalah budaya dan sosial. Dengan demikian fiqh telah mengemban tugas baru sebagai perangkat hermeunetika, yang implikasinya sangat besar dalam kehidupan. Sifat fiqh sebagai perangkat hermeunetika ini di satu sisi mempunyai watak relatif yang sangat tinggi karena itu harus mengakomodasi pluralitas realitas (pluraritas kebenaran), dan karena itu ia harus melunakkan kepastian normatifnya. ${ }^{33}$

\section{Orientasi Dan Formalisasi Fiqh Keindonesiaan}

Ada dua kecenderungan utama tema tentang fiqh keindonesiaan, yaitu cita-cita untuk membangun hukum Islam yang berciri khas Indonesia dengan cara membebaskan budaya Indonesia dari budaya Arab dan menjadikan adat Indonesia sebagai salah satu sumber hukum Islam di Indonesia. Kecenderungan pertama ini ditandai dengan lahirnya konsep-konsep pembaharuan hukum Islam yang kental dengan nuansa keindonesiaan. Misalnya pada awal tahun 1950-an, Hazairin menawarkan konsep "Mazhab Nasional", walaupun bertulang punggung mazhab Syafi'i, tetapi mazhab nasional membatasi ruang lingkupnya pada hukumhukum non-ibadah yang belum diijtihâdikan undang-undang oleh negara. ${ }^{34}$

Kecenderungan yang kedua adalah keindonesiaan hukum Islam yang berorientasi konstitusional. Ini dimotori oleh tokoh-tokoh umum yang menguasai sistem hukum Indonesia, tetapi kurang mendalami prinsip-prinsip "kembali kepada Al-Qurân dan Sunnah". Cita-cita agar hukum Islam diwujudkankan dalam Undang-undang Dasar Negara dicuatkan kembali oleh wakil-wakil umat Islam dalam BPUPKI. ${ }^{35}$

Orientasi konstitusional ini dapat dibagi lagi ke dalam beberapa tahapan, dari sikap yang keras kemudian melunak. Pertama adalah keinginan untuk membangun negara Islam dengan cara menjadikan hukum Islam sebagai Undang-Undang Dasar Negara, seperti tercermin dalam sikap umat Islam dalam sidang BPUPKI, Piagam Jakarta, Negara Islam Indonesia, dan sidang-sidang Constituante. Semua perjuangan ini berjalan sesuai dengan ketentuan hukum yang berlaku, kecuali jalan yang ditempuh Negara Islam Indonesia melalui pemberontakan.

Setelah mengalami beberapa kali kekalahan, kaum reformis memperlunak langkahlangkah mereka. Walaupun tidak lagi mencita-citakan negara Islam, tetapi mereka masih saja harus menyingkirkan rintangan konstitusional, yaitu mengganyang teori resepsi dengan Haizirin yang tampil sebagai tokoh sentral. Dari sini kaum reformis melangkah dengan program Kompilasi Hukum Islamnya. Dari hasil perjuangan kaum reformis tersebut, hukum Islam di Indonesia - setidaknya hingga saat ini - selain telah ditransformasi ke dalam hukum resmi negara, juga telah memperoleh bentuk tertulisnya baik dalam bentuk Undang-Undang maupun Peraturan-Peraturan lain di bawah Undang-Undang, yang mana bagi yang melanggar akan memperoleh sanksi, baik sanksi institusional maupun sanksi adat dari masyarakat, atau setidaknya bagi pelanggarnya akan kehilangan hak-hak tertentunya sebagai warga negara. Dalam kenyataan lebih konkret, terdapat beberapa produk peraturan perundang-undangan yang secara formil maupun material tegas memiliki muatan yuridis hukum Islam, antara lain:

${ }^{32}$ Ibid.

33 Chamim Tohari, Reformulasi fiqh arab menuju fiqh keindonesiaan (telaah sosio-historis dan metodologis, serta formalisasinya sebagai hukum nasional, Jurnal Ulumuddin, Volume IV, Tahun III, Universitas Muhammadiyah Malang, 2009.

${ }^{34}$ Hazairin, Hukum Kewarganegaraan Nasional, Jakarta: Tintamas, 1982, h. 6.

35 Ahmad Syafi'i Ma'arif, Islam dan Masalah Kenegaraan: Studi tentang Peratiran dalam Konstitusi, Jakarta: LP3ES, 1985, hh. 101-126. 
1. UU No. 1 Tahun 1974 tentang Hukum Perkawinan

2. UU No. 7 Tahun 1989 tentang Peradilan Agarna (Kini UU No. 3 Tahun 2006)

3. UU No. 7 Tahun 1992 tentang Perbankan Syari'ah (Kini UU No. 10 Tahun 1998)

4. UU No. 17 Tahun 1999 tentang Penyelenggaraan Ibadah Haji

5. UU No. 38 Tahun 2000 tentang Pangelolaan Zakat, Infak dan Shadaqah (ZIS)

6. UU No. 44 Tahun 1999 tentang Penyelenggaraan Otonomi Khusus Nangroe Aceh Darussalam

7. UU Politik Tahun 1999 yang mengatur ketentuan partai Islam

8. UU No. 41 Tahun 2004 tentang Wakaf

9. UU No. 19 Tahun 2008 Tentang Surat Berharga Syari'ah Negara

10. UU No. 21 Tahun 2008 Tentang Perbankan Syari'ah

Di samping tingkatannya yang berupa Undang-undang, juga terdapat peraturanperaturan lain yang berada di bawah Undang-undang, antara lain:

a. PP No.9 Tahun 1975 tentang Petunjuk Pelaksanaan UU Hukum Perkawinan

b. PP No.28 Tahun 1977 tentang Perwakafan Tanah Milik

c. PP No.72 Tahun 1992 tentang Penyelenggaraan Bank Berdasarkan Prinsip Bagi Hasil

d. Inpres No.1 Tahun 1991 tentang Kompilasi Hukum Islam (yang mencakup hukum perkawinan, kewarisan, dan wakaf Islam)

e. Inpres No.4 Tahun 2000 tentang Penanganan Masalah Otonomi Khusus di NAD

Peraturan Mahkamah Agung No.2 Tahun 2008 tentang Kompilasi Hukum Ekonomi Syariah dan sekian banyak produk perundang-undangan Republik Indonesia yang memuat materi hukum Islam.

Dalam upaya penyusunan fiqh Islam yang bernuansa keindonesiaan ke dalam hukum formal negara, pemerintah sangat memperhatikan situasi dan kultur umat Islam di Indonesia agar perundangan yang dihasilkan nanti tidak kontra dengan adat kebiasaan masyarakat muslim Indonesia. Misalnya dalam penyusunan KHI, Kompilasi yang akan disusun itu dimaksudkan untuk menampung nilai-nilai serta norma-norma hukum yang tumbuh hidup dan berkembang dalam masyarakat Indonesia. Untuk mencapai hal itu, panitia menempuh empat jalur dalam proses penyusunannya sebagai berikut:

1. Pengkajian kitab-kitab fiqih mazhab Syafi'i

2. Mengumpulkan pendapat ulama Indonesia untuk dijadikan masukan dan pertimbangan dalam penyusunan kompilasi tersebut

3. Mengumpulkan jurisprudensi yang terhimpun dalam putusan-putusan Pengadilan Agama seluruh Indonesia sejak masa penjajahan Belanda hingga kompilasi tersebut tersusun

4. Studi perbandingan mengenai pelaksanaan dan penegakan hukum Islam di negara-negara muslim. $^{36}$

Setelah bahan-bahan diperoleh melalui keempat alur tersebut, panitia perumus lalu bekerja menyusun bahan-bahan dimaksud secara "logis-sistematis" dan dituangkan ke dalam pasal-pasal dengan bahasa peraturan perundang-undangan yang berlaku di Indonesia. Oleh panitia perumus telah diupayakan menyusun pasal-pasal kompilasi itu dengan bahasa yang sederhana, mudah dipahami, singkat, walaupun sebagai hasil karya manusia tentunya terdapat banyak kekurangan. Dalam menyusun kompilasi ini pertimbangan kemaslahatan sangat diperhatikan oleh anggota komisi, terutama mengenai hal-hal yang termasuk ke dalam kategori ijtihadi.

Lebih jauh nuansa-nuansa pembaharuan hukum Islam di Indonesia dapat dicermati dalam beberapa bidang, yaitu dalam bidang perkawinan, kewarisan dan perwakafan. Dalam bidang perkawinan, misalnya, terdapat beberapa bentuk pembaharuan seperti pencatatan perkawinan, batas usia kawin, persetujuan calon mempelai, izin poligami, perceraian di depan

${ }^{36}$ Muhammad Daud Ali, Hukum Islam: Pengantar Ilmu Hukum dan Hukum Islam Indonesia, Jakarta: PT Raja Grafindo Persada, 2007, h. 235. 
sidang pengadilan, dan semua tindakan hukum yang merupakan upaya-upaya untuk mewujudkan perkawinan dengan segala akibat hukumnya.

KHI misalnya, telah mengatur secara lengkap tentang rujuk, baik yang bersifat normatif, teknis maupun administratif, yaitu diatur dalam Bab XVIII Pasal 163, 164, 165 dan 166, sedang secara teknis diatur dalam Pasal 168 dan 169. Persoalan yang bukan bersifat normatif tidak disinggung dalam Undang-undang No. 1 Tahun 1974 maupun Peraturan Pemerintah No. 9 Tahun 1975. Sedangkan yang bersifat teknis dan administratif, KHI hanya memperkuat ketentuan-ketentuan yang tertuang dalam Permenag No. 3 Tahun 1975, bahkan hampir semua kata yang dipakai sama. Hal ini dapat dimaklumi karena KHI dibuat untuk memperkokoh atau mencari rujukan undang-undang atau peraturan-peraturan sebelumnya dan menambah yang belum ada. Oleh karena itu, materi KHI tidak hanya terbatas pada satu mazhab, tetapi beberapa mazhab. Pasal 163 (2) point b menegaskan bahwa rujuk tidak dapat dilakukan jika perpisahan itu terjadi disebabkan zina yang pelaksanaannya berdasarkan putusan Pengadilan Agama. Pasal ini juga menegaskan bahwa rujuk dapat terjadi dengan putusnya perkawinan berdasarkan putusan Pengadilan Agama dengan satu atau beberapa alasan. Dalam hal ini, KHI tidak menyebutkan secara rinci, selain zina dan khulu'. Alasan-alasan ini bersifat umum, yakni dapat berwujud istri tidak diberi nafkah, istri selalu disakiti, suami pergi tanpa ada berita dan suami dipenjara. Tentang bunyi Pasal 163 (2) point b, kompilasi berbeda dengan kebanyakan ulama. Menurut KHI, alasan yang dapat dimasukkan ke dalam talak raj' $i$ yang dapat dilakukan rujuk hanya talak yang diputuskan pengadilan karena suami tidak memberi nafkah, sebagaimana pendapat Hanafiyah.

Oleh karena itu, pasal ini merupakan hasil ijtihad ulama Indonesia yang concern terhadap persoalan yang muncul antara suami dan istri. Jika dicermati lebih mendalam, maka pasal ini merupakan pengembangan atau analog dari pendapat ulama Hanafiyah yang memasukkan thalaq raj'i dengan alasan tidak memberi nafkah. Dalam hal ini ditemukan alasan adanya bahaya kepada istri. Pasal 164 KHI menegaskan bahwa mantan istri yang akan dirujuk memiliki hak untuk mengajukan keberatan atas kehendak rujuk mantan suaminya, yang akan merujuk. Artinya, jika dia keberatan dirujuk, maka suami tidak boleh memaksakan kehendaknya untuk rujuk. Pernyataan ini berbeda dengan pendapat mayoritas fuqahâ'. Demikian juga Pasal 165 KHI menegaskan bahwa rujuk yang tidak mendapat persetujuan mantan istri dapat dinyatakan tidak sah dengan putusan Pengadilan Agama. Unsur kerelaan menjadi faktor determinan. Pasal ini juga berbeda dengan seluruh pendapat fuqahâ'. Kewajiban untuk mencatatkan rujuk yang dimaksudkan sebagai bukti otentik dalam kepastian hukum, seperti yang dinyatakan dalam Pasal 165, juga merupakan ketentuan baru dalam proses rujuk.

Dalam bidang kewarisan juga dapat ditemukan beberapa ketentuan yang tidak terdapat dalam fiqih. Menurut bunyi Pasal 49 Undang-undang No. 7 Tahun 1989 tentang Peradilan Agama, hukum waris yang dipraktekkan di Pengadilan Agama adalah Hukum Waris Islam. Selama ini, ketika disebut hukum waris Islam, maka asumsinya adalah hukum waris menurut mazhab Syafi'i atau menurut pendapat Hazairin. Hukum Waris Islam adalah hukum waris yang bercorak patrilineal. KHI ternyata memperkenalkan beberapa cara yang tidak lazim menurut mazhab Syafi'i antara lain tentang pembagian warisan dengan cara damai (Pasal 183), penggantian kedudukan, mawali atau Platsvervullings (Pasal 185), pembagian warisan ketika pewaris masih hidup (Pasal 187), dan ketentuan harta bersama atau gono-gini (Pasal 190).

Demikian pula halnya dengan yang terjadi pada bidang pewakafan. Pengertian pewakafan menurut Peraturan Pemerintah No. 28 Tahun 1977 Pasal 1 dan KHI Pasal 215 adalah perbuatan hukum seseorang atau kelompok orang atau badan hukum dengan cara memisahkan sebagian dari harta benda miliknya dan melembagakannya untuk selama-lamanya guna kepentingan ibadah atau keperluan umum lainnya sesuai dengan ajaran Islam. Prinsip mu'abbad pada dasarnya dianut oleh semua mazhab fiqih. Namun dalam perkembangan 
selanjutnya terdapat variasi lain. Contoh, dalam PP No. 28 Tahun 1977, Bab IV Pasal 11 ayat 1 dinyatakan: "Pada dasarnya terhadap tanah milik yang telah diwakafkan tidak dapat dilakukan perubahan peruntukan atau penggunaan lain daripada yang dimaksud dalam ikrar wakaf". Tampaknya pasal ini berangkat dari prinsip mu'abbad dalam wakaf, disamping untuk memelihara kelestarian benda wakaf. Tetapi penyimpangan dimungkinkan dengan tercantumnya ayat 2 pada bab dan pasal yang sama. Disebutkan bahwa "Penyimpangan dari ketentuan tersebut ayat 1 hanya dapat dilakukan terhadap hal-hal tertentu setelah terlebih dahulu mendapat persetujuan tertulis dari menteri agama, yakni (a) karena tidak sesuai lagi dengan tujuan wakaf seperti yang diikrarkan oleh wakif dan (b) karena kepentingan umum.

Ketentuan lain yang perlu disebutkan adalah mengenai kewajiban untuk mendaftarkan benda wakaf (Pasal $223 \mathrm{KHI}$ ). Sebenarnya masalah pencatatan atau sertifikasi wakaf lebih dekat untuk diqiaskan kepada soal utang-piutang (Q.S. Al-Baqarah : 282). Namun pencatatan ini belum disinggung dalam kitab-kitab fiqh. Itu artinya sekarang ini, rumusan yang dikemukakan dalam kitab-kitab fiqh pengamalannya perlu dilengkapi dengan penambahanpenambahan yang bersifat yuridis adiministratif. Ini dimaksudkan untuk meningkatkan jangkauan kemaslahatan yang ingin dicapai oleh pelaksanaan wakaf itu sendiri, misalnya, dengan disertai akta ikrar wakaf atau pengganti akta ikrar wakaf atau sertifikat tanah wakaf.

Sejalan dengan perubahan iklim politik dan demokratisasi di awal tahun 1980-an sampai sekarang, tampak isyarat positif bagi kemajuan pengernbangan hukum Islam dalam seluruh dimensi kehidupan masyarakat. Pendekatan struktural dan harmoni dalam proses Islamisasi pranata sosial, budaya, politik, ekonomi dan hukum, semakin membuka pintu lebarlebar bagi upaya transformasi hukum Islam dalam sistem hukum nasional. Tinggal bagaimana posisi politik umat Islam tidak redup dan kehilangan arah, agar ia tetap eksis dan memainkan peran lebih besar dalam membesarkan dan memajukan Indonesia baru yang adil dan sejahtera.

\section{PENUTUP}

Dari uraian di atas dapat disimpulkan bahwa munculnya gerakan reformasi di Indonesia terhadap konstruksi hukum Islam yang telah ada yang selanjutnya melahirkan sebuah konsep fiqh yang lebih berbasis lokal Indonesia, yang lebih aktual untuk dapat diterapkan oleh masyarakat muslim nusantara, itulah yang dikatakan sebagai fiqh keindonesiaan.

Hasbi As-Shiddiqi dan Hazairin merupakan dua tokoh penggagas fiqh model keindonesiaan tersebut, selain para cendikiawan lainnya yang tidak kalah penting peranannya dalam pembaharuan hukum Islam di Indonesia. Hasbi Hasbi termasuk salah seorang pembaharu yang menawarkan ide-idenya secara komprehensif, mulai dari konsep "fiqh Indonesia"-nya, sampai pembaharuan hukum yang meliputi prinsip dan sekaligus metodenya. Sedangkan Hazairin mengusulkan pengembangan suatu sistem warisan baru yang diinterpretasikan dan dielaborasikan berdasarkan persepsi skriptual al-Qur'an dan Sunnah bukanlah sistem patrilineal, tetapi bilateral, yakni model kekeluargaan formalisasi konsep fiqh yang bernuansa keindonesiaan tersebut ke dalam tata hukum di Indonesia telah menghasilkan beberapa produk peraturan perundang-undangan penting yang secara formil maupun material tegas memiliki muatan yuridis hukum Islam yang telah berakulturasi dengan kondisi masyarakat Islam di Indonesia, seperti UU tentang Hukum Perkawinan Islam. Di samping tingkatannya yang berupa Undang-undang, juga terdapat peraturan-peraturan lain yang berada di bawah Undang-undang, Seperti PP, Inpres dan Peraturan Mahkamah Agung, dan Kompilasi Hukum Islam dan Kompilasi Hukum Ekonomi Syariah. Harus diakui bahwa tidak semua ide dan pemikiran para penggagas pembaharuan hukum Islam di atas dapat terealisasi dalam UU formal, tetapi karena spirit perjuangan mereka dalam penciptaan mazhab nasional itulah yang sangat mempengaruhi terbentuknya formalisasi hukum Islam ke dalam sistem hukum di Indonesia. 


\section{DAFTAR PUSTAKA}

\section{Buku}

Abdullah Ahmad An-Na'im, Dekonstruksi Syari'ah, terj. A. Suaedi dan Amiruddin, Yogyakarta: LkiS, 1997.

Abdullah Ahmad An-Na'im, Shari'a and Islamic Family Law: Transition and Transformation, New York: Emory University, 2002, h. 20.

Ahmad Syafi'i Ma'arif, Islam dan Masalah Kenegaraan: Studi tentang Peratiran dalam Konstitusi, Jakarta: LP3ES, 1985.

Bassam Tibi, Islam and the Cultural Accommodation of Social Change, terj. Clare Krojl, Boulder : Westview Press, 1990, h. 66.

Haidar Nashir, Muhammadiyah Gerakan Pembaharuan, Yogyakarta: Suara Muhammadiyah, 2010, h.62.

Hamka, Antara Fakta dan Khayal "Tuanku Rao", Jakarta: Bulan Bintang, 1974.

Hasbi as-Shiddiqi, Syari'at Islam Menjawab Tantangan Zaman. Yogyakarta : IAIN Sunan Kalijaga, 196.1 , Beberapa Permasalahan Hukum Islam. Jakarta : Tintamas, 1975.

, Dinamika dan Elastisitas Hukum Islam. Jakarta : Tintamas, 1975.

Hazairin, Hukum Kewarganegaraan Nasional, edisi ke-3, Jakarta : Tintamas, 1982.

Hazairin, Hukum Kewarisan Bilateral Menurut Qur'an dan Hadis, Jakarta: tp, 1982.

J.N.D. Anderson, Islamic Law in the Modern World, Connecticut: Greenwood Press, 1975.

M. Naquib Al-Attas, Islam and Secularizm, Kuala Lumpur: Abim, 1978, Bandung: Pustaka, 1981.

Masdar F. Mas'udi, Agama Keadilan :Risalah Zakat (pajak) dalam Islam, edisi ke-3, Jakarta : $\mathrm{P} 3 \mathrm{M}, 1993$.

Muhammad Atho Mudzhar, Fatwa-fatwa Majelis Ulama Indonesia: Sebuah Studi tentang Pemikiran Hukum Islam di Indonesia, 1975-1988.Jakarta: INIS, 1993.

Muhammad Daud Ali, Hukum Islam: Pengantar Ilmu Hukum dan Hukum Islam Indonesia, Jakarta: PT Raja Grafindo Persada, 2007.

Munawir Sjadzali, Reaktualisasi Ajaran Islam, dalam Polemik Reaktualisasi Ajaran Islam, ed., Iqbal Abdurrauf Sainima, Jakarta : Pustaka Panjimas, 1980.

N.J. Coulson, A History of Islamic Law, Edinburgh: Edinburgh University Press, 1971.

Nourouzzaman, Muhammamad Hasbi Ash Shiddieqy dalam Perspektif Pemikiran Ulama di Indonesia. Disertasi Doktor, IAIN Sunan Kalijaga Yogyakarta. 1987.

Quraish Shihab yang berjudul Jilbab, Pakaian Wanita Muslimah, Jakarta: Lentera Hati, 2004. , Perempuan, Jakarta: Lentera Hati, 2005. , Membumikan Al-Qur'an, Jakarta : Mizan, cet. Ke-18, 1994.

Saifuddin Zuhri, Sejarah Kebangkitan Islam dan Perkembangannya di Indonesia, Bandung: AlMa'arif, 1979.

\section{Artikel atau Jurnal}

Ahmad Zain An-Najah, makalah Majlis Tarjih Muhammadiyah : Pengenalan, Penyempurnaan Dan Pengembangan, Kairo : 2004.

Chamim Tohari, Reformulasi fiqh arab menuju fiqh keindonesiaan (telaah sosio-historis dan metodologis, serta formalisasinya sebagai hukum nasional,Jurnal Ulumuddin, Volume IV, Tahun III, Universitas Muhammadiyah Malang, 2009.

Michael Feener, Gerakan Indonesia Menuju Mazhab Nasional, Jurnal Ulumuddin, Volume IV, Tahun III, Januari-Juni 2009.

Minhaji, Akhmad, "Islamic Reform in Contest : Ahmad Hasan and His Trodisionalist Oppenents". Studia Islamika, vol. 7 no. 2. Th. 2000. 